\title{
A conceptual framework for effective organizational adoption of social technologies
}

\author{
Shaheen Khatoon* \\ College of Computer Science and Information Technology, Department of Information Science, King Faisal University, Al Ahsa, \\ Saudi Arabia
}

\section{A R T I C L E I N F O}

Article history:

Received 20 May 2016

Received in revised form

28 August 2016

Accepted 22 September 2016

Keywords:

Social Technologies

Social Networking

Social technologies in organizations

Employee Engagement

Customer Engagement

Stakeholders Engagement

Conceptual Framework

\begin{abstract}
A B S T R A C T
In this study by focusing on social network sites, wikis, microblogging, video sharing, among others, we identify perspective beneficial attributes of these technologies to support business activities in context of organizational operations and internal/external communication. Specifically, this study seeks to answer three questions: i) What organizational activities can be enhanced by using social technologies, ii) what business value an organization can gain and, iii) how to engage employee, customers and other external stockholders through use of these technologies. In doing so this study reviewed the existing literature in order to identify how organizations can take advantages of social technologies to facilitate their various business activities. Base on features identified from existing studies, a conceptual framework is proposed which includes various conceptual models for effectively adopting social technologies in different organizational activities. We believe this study will help organizations to identify potential business activities and to develop adequate strategies to deploy social technologies in workplace.
\end{abstract}

(C) 2016 The Authors. Published by IASE. This is an open access article under the CC BY-NC-ND license (http://creativecommons.org/licenses/by-nc-nd/4.0/).

\section{Introduction}

Social technologies wikis, social networking sites, micro-blogging sites, and video-sharing sites are online tools that allow users to share contents, collaborate, and build networks and communities, with the possibility of reaching and involving large audiences. Being built on web 2.0 these technologies are collaborative and interactive that can able to deliver updated services in real-time. As a result, these technologies has created new opportunities for organizations to improve their internal business operations and to collaborate in new ways with their customers, business partners, investors, and suppliers. Therefore, organizations are beginning to recognize the substantial potential of social technologies inside the organization and with external world.

Our last few years using social media has open many opportunities for organizations due to its feature that can enhance communication, interaction, learning and collaboration which can bring significant benefit to organizations. For example, according to a study by McKinsey

\footnotetext{
* Corresponding Author

Email Address: sha.xin@live.com

https://doi.org/10.21833/ijaas.2016.09.012

2313-626X/C) 2016 The Authors. Published by IASE.

This is an open access article under the CC BY-NC-ND license

(http://creativecommons.org/licenses/by-nc-nd/4.0/)
}

consultants (Bughin et al., 2009), 69 percent of respondents report that their companies have gained considerable business benefits, including more innovative products and services, more effective marketing, better access to knowledge, lower cost of doing business, and higher revenues. Therefore, use of social media in government, public relations (McLennan and Howell, 2010), transport (Gal-Tzur et al., 2014), health care (Hawn, 2009), agencies and enterprises has increased dramatically for communication, marketing, recruitment and policy development. These organizations cannot afford their absence on the social channels if their competitors are making waves with their products and services. Organizations make their presence by providing link to Facebook, Twitter, YouTube and other platform, from their own websites. They often use these technologies for their internal and external collaboration. Internally, they are using for internal communication and knowledge transfer, to reach personnel and to conduct internal primary business functions. Externally, they are using to enhance communications related to the company brand, to enable dialogue with customers, to build communities with various stakeholder groups and to engaging external stakeholders including investors, customers and general public.

However, to implement such technologies at workplace organizations need to know where they can get benefited and how to measure their 
effectiveness. To do so, organization should develop appropriate means and criteria for measuring social media effectiveness. If effectiveness is measured in terms of customer relationships or employee engagement, setting up tools through which organizations can identify and understand their intentions is extremely important as well as understanding their different needs of involvement within the diverse organization's processes. In other words, it is not possible to measure the real value of social technologies without knowing what business activities can be enhanced.

However, it has been observed that firms often fail to fully exploit the capability of social platforms. This lead us to believe that the usefulness and potential of social platform should be studied empirically, especially in the context of how effectively organizations can use it in various activities and subsequently how businesses can gain value by exploiting social platform. Following are the research questions which are addressed by this study:

- What are the areas where organization can use social technologies to enhance business activities by using social technologies?

The role of this question is to identify organizational major business component where frequent information flow occurs within and outside the organization and technologies can be applied to enhance collective organizational performance.

- What organizational activities can be supported in identified area by use of Social Technologies?

The aim of this question is to identify main process in each area where the social technologies were applied. The most frequent domain with their general process flow will be identified as well as any new domains suggested.

- What values organization can gain through such activities supported by Social technologies

The aim of this question is to identify specific value e.g. cost reduction, customer retention, revenue generation etc. in each domain.

- What are external and internal barriers to achieve specific business value?

The role of this question is to identify environmental factors impede to gain certain value. For example, influence of organizational culture, social, political and economic factors on effective usage of such tools.

\section{Social technologies usage by organizations}

Published literature on adoption of social technologies across industries is evaluated to identify where social technologies can be used, what kind of business activities are supported and how they are gaining business value. After a comprehensive analysis on prior research on social media for business activities we found that social technologies can be used within any functional area of organization which needs information exchange. Fig. 1. shows information flow of organization where social technologies can be integrated to achieve business process efficiency by fostering internal and external communication. The purpose of internal communication is to organize work within the firm, thereby adding value to the product and/or service. It mainly includes firm level and employee engagement to perform organizational primary functions. On the other hand, external communication using social technologies is to reach wide range of audience including customers and stakeholder's engagements to achieve long term objectives.

A review of the literature on organizational given the idiosyncrasies of internal and external communication we reveal that Social Media platforms yields a number of potential usage to organizations, which may be broadly classified in terms of: 1) Organizational level use of technologies, 2) employee uses of the technologies, 3) customer engagement activities, and 4) external partner activities. Fig. 1. Shows social business model we followed to organize literature.

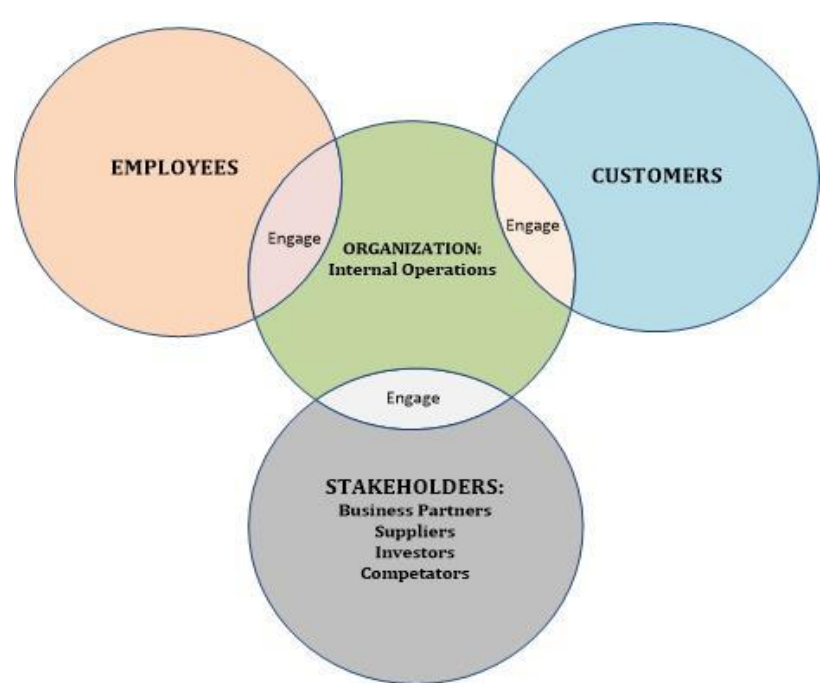

Fig. 1: Categorization of social technologies usage for connecting organization with employee, customers and stakeholders

\subsection{Firm level usage}

Organization can get benefit of social technologies to support their primary functions such as providing customer service and support, product development, Human Resource Management (HRM), knowledge management developing, firm competitive intelligence etc.

At corporate level one important use of social technologies is to develop organizational Competitive Intelligence (CI). It includes collecting and analyzing intelligence about competitor's products, promotions, sales etc. from external sources such as people, events, consumer's sentiments, competitor strategies etc. (Dey et al., 2011; He et al., 2013). In this context social technologies can leverage the process of accessing and collecting data from wide range of user in real time. Organizations use competitive intelligence to identify risks and opportunities in their markets, 
which enable them to make informed decisions and reduce reaction cost. Empirical studies found that the effect of social media-based corporate strategies on firm performance by monitoring customer communications, feedback and opinions (Schniederjans et al., 2013). By performing text mining on dataset collected from blog, forums and corporate websites they find that corporate level strategies enable by social technologies improve firm's financial performance. Also (Yu et al., 2013) performed sentimental analysis on different social media and identified that overall social media combined with traditional media and stock performance are strongly correlated. Based upon stock performance firm can better plan their investments and foresee risk. Similar kind of study is conducted by (Luo et al., 2013) to predict firm equity value by utilizing social media data. Their finding show that social media based matrices predicts firm equity value better, faster (shorter time) and more accurately as compare to traditional media. Lee et al. (2013) explored whether Corporate Social Responsibility (CSR) influence the firm's social media adoption. They analyzed Fortune 500 companies in the Twitter sphere and results reveals that a higher CSR rating is a strong indicator of an earlier adoption, a faster establishment of online presence (followers), a higher responsiveness to the firm's identity (replies and mentions), and a stronger virility of the messages (retweets). Medium and large firms are adopting social platform to discover new knowledge e.g. product popularity and interesting patterns to understand what their competitors are doing and how the industry is changing (Lau et al., 2005; He et al., 2013). Furthermore, continuous communication with customers can be used for solution development by utilizing customer opinions in making key product decisions and other marketing policies. Social networking and social media platforms can encourage customers to submit and vote on new product ideas. In turn it may help lowering costs for research and development by learning directly from the customers about their needs. It is believed that firms using social media for competitive intelligence are more proactive, providing better customer satisfaction and business value.

One of the areas where social technologies have the biggest impact on organizations is in the communication and interaction with costumers, the public and other stake holders. This communication can build and improve customer relationship by providing them direct access to information and enhance organizations' perceived image or brand (O'Leary et al., 2004). Prior studies have shown that communication via social media can exert a huge influence on attitudes and purchasing behaviors of peers. The most important reason for businesses to emphasize social media use is for marketing and promotion. As compare to traditional advertisement such as newspaper and other media social media is more affordable for small and medium organizations. It also has potential to reach wide audience and target marketing (Wang et al., 2012). Furthermore, the literature claims that, through social media it is possible to perform integrated marketing activities with much less effort and cost (Kim and Ko, 2012).

Social technologies can also assist organizations to create an online knowledge management platform containing the accumulated wisdom of the organization, by allowing knowledge to be codified, searched and shared. By decreasing the use of emails and other disruptive communication methods, the use of blogs and wikis, can increase productivity and work flow efficiency (Du Plessis and Boshoff, 2008).

Another implication of social media usage for organizations is how they hire and manage their employee. In this direction a study conducted by (Brown and Vaughn, 2011) shows that HR is using social media to seek best candidate. However, highly unstructured information and originality of information are major challenges. Furthermore, use of such personal information for human resource decisions could be regarded as an invasion of privacy. Additionally, social technologies can be used by HR management to monitor worker. By making the activities and contribution of employee more visible firms may increase surveillance of worker. Research by (Giordano, 2007) suggests that workers may reluctant to contribute works-in-progress due to fears of accountability and control.

\subsection{Employee engagement}

Apart from strategic level users another significant facet for organizations is their employees from entry to top level positions. Organizations need practical guidance on how to incorporate social media to motivate, manage usage into their human resources strategies and policies. For example, what are effective ways for using social media to recruit suitable employees and foster their engagement in knowledge creation and sharing, commitment and loyalty to the firm. Many organizations have adopted social media platforms internally to facilitate communication, collaboration and knowledge management and sharing as well as employee training and learning. In current knowledge driven economy, it has been observed that knowledge contributions from members/employee have significant positive impact on organizational performance. Therefore, organization are adopting social technologies as useful knowledge sharing tool for knowledge management in a collaborative work environment. However, trust has been recognized as an important factor of fostering knowledge sharing in organizations. In this line of study Chai and Kim (2010) conducted a survey of 485 college students to identify knowledge sharing behavior. Since bloggers share information and knowledge through posting/ updating/ giving feedback and commenting on knowledge contents. Therefore, knowledge sharing behavior can be identified from bloggers frequency 
of doing these activities. Furthermore, they identified trust in other bloggers, trust in the economic benefit of sharing knowledge and trust in the blog service provider positively affect the creation and sharing of knowledge in blogs.

A case study conducted by Huh et al. (2007) on IBM's BlogCentral platform participation found that blogs were facilitates access to individuals' tacit knowledge and contributes to the emergence of collaboration across a broad range of communities within the enterprise. The blogs were useful for capturing tacit knowledge because talking about one's expertise in a public forum forced individuals to demonstrate how they conducted tasks. Some studies examine that use of social technologies in knowledge sharing and creation efforts can be contingent on organizational support for knowledge management tools and expected benefit and reward for such usage (Davison et al., 2014).

Use of social technologies can also fosters employee horizontal and vertical communication within organizations (Davison et al., 2014). An empirical study conducted by Trimi and Galanxhi (2014) showed that both manager and employee believe that use of social technologies have a positive impact on communication, collaboration, community building, and employee engagement. Empirical studies also showed social media usage for internal communication can enhance communication process in a cost and time-efficient manner (Denyer et al., 2011).

Another important usage of social technologies is the provision of a collaborative learning environment for employee, in which problems are collectively solved and solutions are shared among peers, bridging the gap between procedures and practice. Studies also showed use of social media by employees in informal learning and training. These technologies are claimed to improve organizational performance if integrated with workplace training and formal learning (Zhao and Kemp, 2012). Empirical findings showed use of these technologies in workplace enable team learning create collaborative learning and virtual social environments which are useful in mentoring employees (Bosch-Sijtsema and Haapamäki, 2014). Furthermore, studies found social technologies are emerging as popular educational tools in the workplace is due to their flexible access, timely delivery, and cost-effectiveness (Wang, 2011).

Social technologies also influence employee to monitor coworker activities. In this direction (Wattal et al., 2009) examined log data from 2,667 employees at a multinational electronics corporation. The study found that blog usage of one's manager increases the likelihood of blog usage of subordinate. A similar study is conducted by (Farzan et al., 2008), where they implement an incentive based system that rewards contribution with points. Study found that visible incentive increase participation and contribution.

\subsection{Customer engagement}

Social technologies allow organizations to connect with their customers, provide information and experience and obtain customers input. Customer engagement focuses on customers and their needs in order to engage with them. Customer center approach includes both marketing concept and customer engagement. In customer engagement firm focus on engaging customer for their awareness, satisfaction, retention, loyalty and increase purchase. Whereas, in marketing domain is broader by further including other market forces like competitor (Hadcroft and Jarratt, 2007). Only by meeting the needs of customer firm can meet their own need. By realizing importance of customers in their business success organization has expanded the traditional role played by customer and includes them in the value-adding process by helping firms to understand customer needs, participating in the product development process, providing feedback on strategies and products, and becoming advocates for the product. The use of social media greatly facilitates the process of establishing relationships in term of branding, company image enhancement, better customer services and support which leads to a greater customer satisfaction, retention, loyalty and advocacy. For example Trainor et al. (2014) examined how social media and its interaction with Customer Relationship Management (CRM) affect customer relationship performance. By empirically analyzing data from 308 top executive of US firms they find companies who combined CRM techniques with social technologies developed capabilities to better serve customer needs.

In an empirical research conducted by (Laroche et al., 2013) explored how brand communities based on social media influence customer and increase brand loyalty. Finding shows brand communities established on social media has positive influence on relationship between customer and product/brand/company/product/brand/

company/ another customer and in turn increase brand loyalty. Furthermore, a research on Facebook user generated contents and marketer generated content (Goh et al., 2013) showed that customer engagement on social media brand communities lead to increase customer purchase expenditure. As compare to the direct message by firm, indirect messages among customer and firm has a stronger effect on repetitive purchase behavior of consumers. Also study conducted by (Rishika, 2013) showed customer participation in firms social media efforts lead to increase in frequent customer visits and purchase behavior which in turn increases customer profitability and loyalty. This effect is positively reinforced with loyal customers and a greater level of firm activity on the firm social media site.

\subsection{Stakeholders engagement}

Another use of social technologies in organization is collaborating with stakeholders such as investors, suppliers, potential business partners and third sector organization who are actively involved in the 
project, or whose interests may be positively or negatively affected as a result of project execution or successful project completion. However very little has known about social media use for external audiences other than customers. Although good communication with investors and the general public to firms' financial future is important.

In this sense stakeholder's engagement is a major corporate level responsibility where organization interact with stakeholder in identifying, dialoguing and engaging them by taking their opinion and expectation. Among the traditional techniques of stakeholder engagement integrating stakeholder's participation by using social technologies such as social media, social networks, blogs, websites, and other technologies linked to the internet can increase organization competence and performance (Kent et al., 2003). Huge amount of research is conducted on powerful usage of social media and social networks for reaching and keeping in touch with a large number of stakeholders for wide and easy reachability thus, guaranteeing an interactive dialogue with them at very low costs. Social technologies can contribute in process of creating dialogue with stakeholder to initiate a dynamic context of interaction and mutual respect. As a result, stakeholder engagement is not only limited to manage their expectations, but to create a network of mutual responsibility.

Social technologies allow organizations to engage external stakeholders in continuous conversations. Firms can easily update content on social media and send periodic reminders to external stakeholders to maintain stakeholders' active involvement. By doing so firm can maintain good relationship by keeping them engaged and increase loyalty among external stakeholders (Laroche et al., 2013). Also from stakeholder's perspectives social technologies offered them the opportunity to express themselves by sharing their thoughts, ideas, and opinions freely.

Similarly, by actively monitoring stakeholders' activities and listening to investors' voices attentively, firms can learn about market sentiment and deliver this information to management to take timely action before negative sentiment affects organizational reputation. Additionally, collected information can turns into a valuable resource for performance assessment, as the firm can quickly detect problems from the stakeholders' reactions (Gilbert and Karahalios, 2010).

Social technologies can be used to enhance B2B relationships by reducing the number of suppliers and increasing the level of collaboration between supplier and business customers. Jussila et al. (2014) presented an empirical research of social media in the specific context of companies that operate in business to business (B2B) markets. They presented the survey of 125 B2B companies in Finnish technology industry and found that there is a gap between the original social media and the social media using with consumer in business-to-business company. Since in B2B legal contracts can become challenges in the free disclosure of product or business ideas in inter organizational innovation and collaboration hence limit the usability of social media between B2B companies.

\section{Methodology}

To illustrate the effective use of social media for organizational business activities an empirical study is conducted. We focus on social platforms usage in organizations as opposed to social media use generally with the perception that people utilize technology differently as compare to those who used in workplace. Literature showed high level of use and interaction of social technologies influences greatly the business environment and it appeared to have engendered new paradigm where communication and collaboration create wider networks for the employees, customers and all the partners of the organizations. As a result, organizations are shifted from online we based system to interactive social engagement where consumers can interact, collaborate and participate in different organizational operations. Based on these finding a conceptual model of social technologies usage by organization is shown in Fig. 2. It can be observed from Fig. 2 that this study focused on effective usage of social technologies to enhance overall firm performance, that could be achieved by effectively engaging employee, customers and other stakeholders. In doing so study identified potential usage of these technologies at different level of organization. In subsequent sections we derive potential uses of each level from existing literature and proposed integrated conceptual framework for effective adoption of social technologies by highlighting main activities supported and factors (internal and external) influenced on effective adoption of these technologies.

\subsection{Firm level}

Empirical evaluation of previous studies reveals that organizations use social media effectively for various tasks such as enhancing intelligence by mining innovative ideas, CRM and HRM practices, better promotion and marketing, improve knowledge management, communication and collaboration practices. Effective use of social technologies has a positive impact on organizations, especially in terms of cost reduction improvement in customer relations, and enhancement in information accessibility. However, usage of such technologies in organization is highly dependent on organizational strategic planning for social technologies usage, organizational size and culture. Social technologies usage may have affected by individual usage of these technologies. For example, upper level managers need aggregate and external information to help them make strategic decisions while lower level managers need more detailed, timely information to help them make operational decisions. Therefore, it 
is believed media usage will differ based on level of user in organizational hierarchy.

For example, organizational CRM is highly influenced by the activities used by the marketing team to manage the value exchange between the company and the customers. Furthermore, usage will differ based on the functional area of the user such as marketing, management, product development (Chidambaram et al., 2001).

Based on organizational primary functionality, organizational strategic and environmental factor as well as individual's usage of social technologies a conceptual model for effective usage of social technologies is presented in Fig. 3.

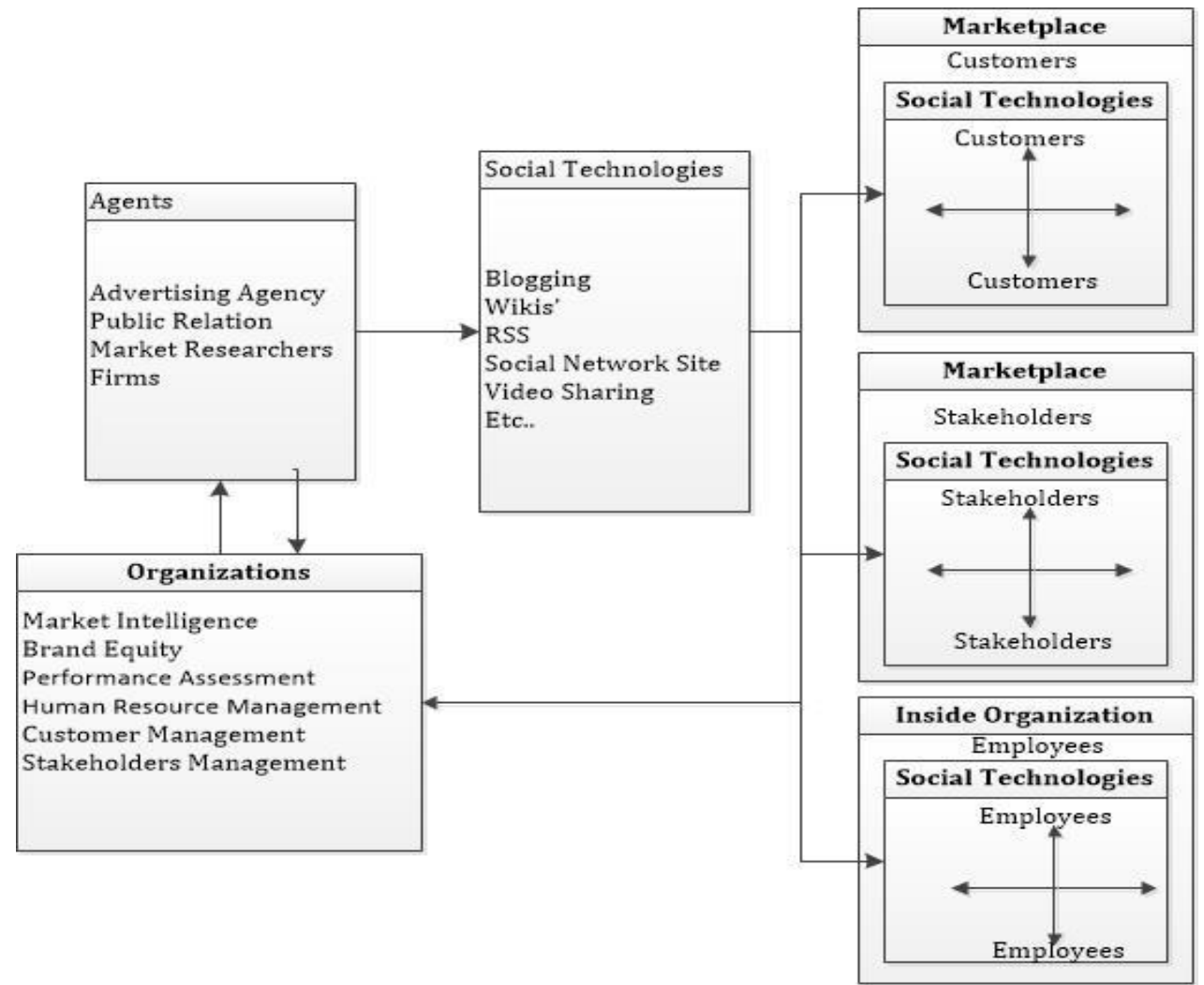

Fig. 2: Conceptual Model of social Technologies usage by Organizations

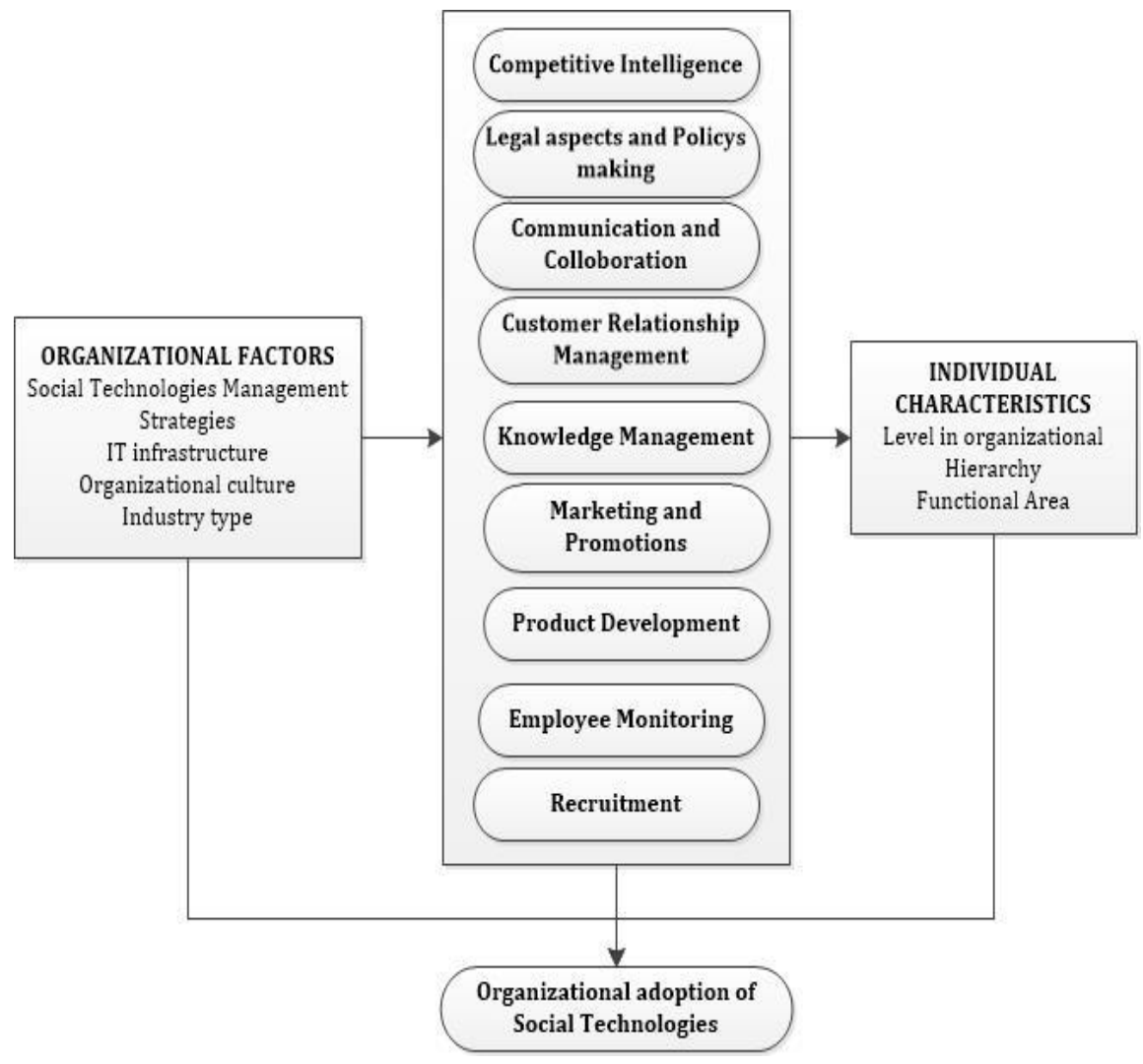

Fig. 3: Conceptual Model for Effective usage of social technologies at firm level 


\subsection{Employee engagement}

It is the degree to which employees are fully involved in their work and the strength of their commitment to their job and the company. HR need practical guidance to build a committed workforce in order to get higher productivity, better customer service and lower employee turnover. From literature review it is identified implementing social technologies in organization foster employee's engagement in knowledge creation and sharing, internal communication process, training and learning as well as monitoring co-workers and organizational activities. However, some studies showed examine that use of social technologies in employee engagement can be contingent on organizational strategic planning and their support for knowledge management and other tools and expected benefit and reward for such usage (Davison et al., 2014). Based upon factors identified from literature a conceptual framework for effective usage of social media for employee engagement is presented in Fig. 4.
In an increasingly networked society customers' engagement is easy. It may take in different form such as word of Mouth, blogging, providing customer ratings, etc. To get benefit from active customer participation via social technologies firm can focus their attention in three direction of communication such as firm to customer, customer to firm and customer to customer. Effective use of social technologies can enhance relationship in these directions. In firm initiated dialogue firm can effectively use these technologies to position their brand, establish a clear message to public distribute time sensitive information, promote their product etc.

In customer to firm direction, firm can capture customer feedback and allow them to participate in the value adding process of product development and collaborate with sellers in creating value. Since social networking has enable more frequent, faster, and richer interactions among much larger groups of connected individuals and organizations or communities.

\subsection{Customer engagement}

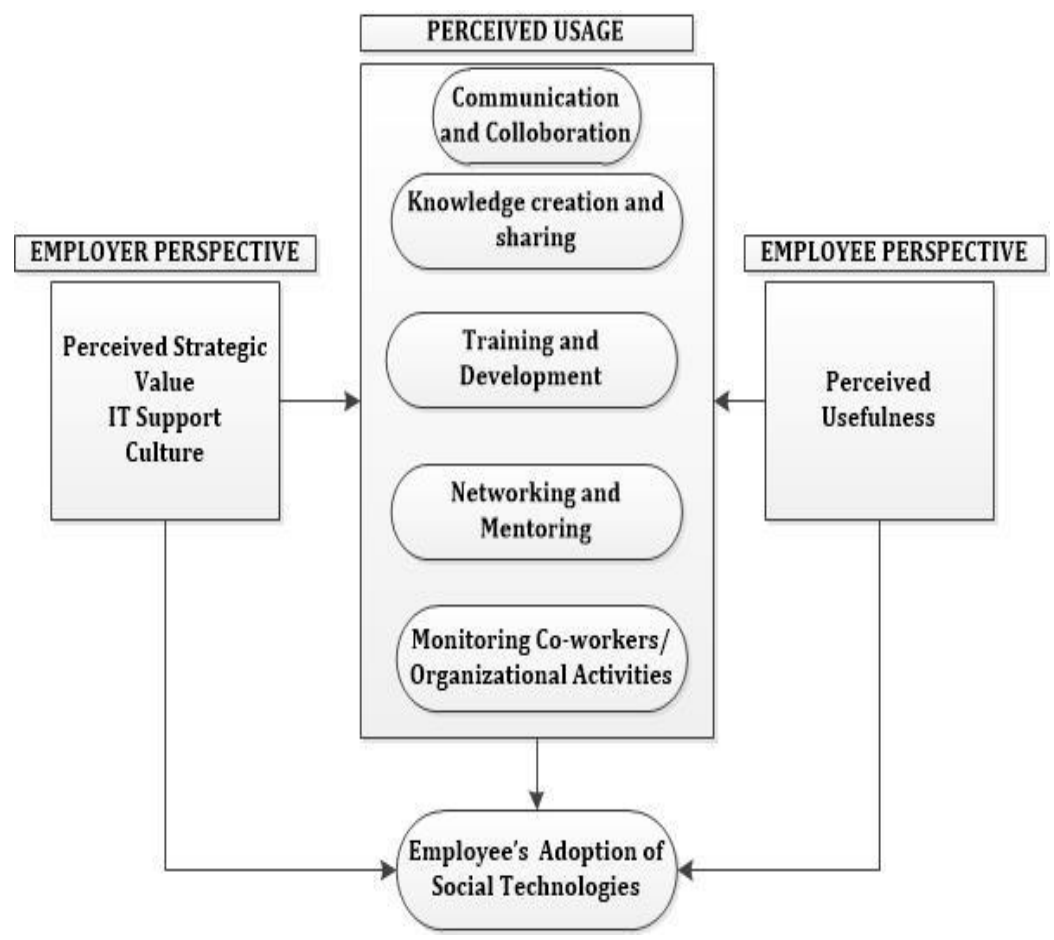

Fig. 4: Conceptual Model for Employee Adoption of Social Technologies

Organization can take benefit of real time interaction to understand and improve customer need specially changes in needs over time. As a result, it can facilitate them in product modifications or the development of new products to better satisfy market needs (Sashi, 2012). The third direction where firm can take advantage of social technologies is inter customer interaction. Customer always interact with each other using Facebook wall posts, tweets, comment fields, and discussion forums.
Organizations can actively monitor this intercustomer dialog to capture customer insight as well as market intelligence.

In this three-dimensional communication customer satisfaction is necessary to keep them engaged which subsequently have an impact on firm overall value creation and profitability. However, high level of satisfaction for product and service is achieved with total purchase over time which leads to long term relationship hence high level retention 
and loyalty (Gustafssonn et al., 2005). Loyal customers become the advocate of product and recommend to others by word of mouth, blogs, social networking etc. which lead to increase profitability. A conceptual model for customer engagement is shown in Fig.5. The basic idea of this framework is that, if the firm allows interactive participation and satisfies particular needs of a customer, this satisfaction should lead to a higher level of brand loyalty and customer retention. Loyal customer recommend product to others which lead to increase purchase as well as shows their commitment with product by favoring or following independent of their purchase decision. In conceptual model some impediments for customer engagements are also considered, for example participation may vary from individual to individual such as some may provide product review/ranking or participation behavior may be affected by provision of certain incentives. Similarly, firm strategies for number of channels provided for customer interaction may effect on customer profitability. Furthermore, environmental factor such as societal welfare and economic welfare also plays a major role on effective usage of these technologies.

\subsection{Stakeholders engagement}

Prior studies showed stakeholders engagement and organizational performance are strongly positively correlated. Therefore, organization are continuously using social technologies to communicate with, involve and develop relationship with wide range of stakeholders. In traditional stakeholder's engagement process project team have to identify and prioritize a project's key stakeholders, develop an appropriate engagement strategy and communications plan to ensure that the needs and expectations of these key stakeholders are understood and managed. Social technologies could facilitate the whole process of identifying and prioritizing the stakeholders where connectivity and relationship play an important role. Unknown stakeholders can be identified on the dimension of connectivity and content share. Furthermore, organization can collect and aggregate their responses efficiently to get a deeper understanding of external stakeholders. By observing stakeholder's action organization can take timely action before negative sentiment affects organizational reputation hence, help them to assess their performance (Gilbert and Karahalios, 2010). Also organization can maintain their Image/reputation by sharing their information to cultivate positive impression of the company in external stakeholders' minds. Social technologies such as wikis' allow firms to record communication with stakeholders and stakeholders' can read and review these communications by making them available. Furthermore, stakeholders can express their opinion and expectation as well as can make connection with other stakeholders. However, the process of engaging stakeholders is highly influenced by organizational strategic plan, type and culture of organization. Based on these factors a conceptual model for stakeholders' engagement is shown in Fig. 6.

\section{Measuring business value gained by using social technologies}

Firms potentially gain value from different activities supported by social technologies. By quantifying the value added by consumers' organization could clearly define strategies of adopting them on workplace.

The value provided by these activities can be measured by using performance indicator developed for measuring outcome of traditional information systems. We can adopt these performance indicators to measure value gain through adopting social technologies:

Financial: Organizational can achieve some financial benefit by using social technologies such as cost reduction, cost avoidance, or revenue generation. Social media can boost organizations profit by lowering cost of advertisement, increase sale due to increased customer satisfaction, improve product quality due to involving them in product development cycle, decrease communication cost by switching from traditional phones to social media.

Organizational effectiveness: Another aspect of measuring outcome of social technologies by assessing the effectiveness and efficiency in of various operations. For example, increased efficiency in developing products due to customer feedback at various stages, improved service time, manage process efficiently such as shortening development cycle, improve quality of work, or customer satisfaction or retention. Increasing organizational efficiency and customer satisfaction will generate revenue and lower cost. E.g. happy customer more likely to buy again.

Individual benefits: Such as increase awareness, learning and skill development as well as employee satisfaction and retention.

System e.g., measures related to IT performance or information security and management.

Table 1 provide an overview of which activities are supported by social media and what specific business value organization gain.

\section{Conclusion and future work}

With the advent of unique features of social technologies such as social network sites, wikis, microblogging, video sharing and others, more and more organizations are using them. But simply providing an online presence by using these technologies is not sufficient to ensure maximum business gain. By reviewing the existing literature on organizational usage of social technologies this study provides valuable insights on the effective usage of social technologies by any organization. We identified successful implementation of social technologies for its basic operations internal and external communication require three main 
questions to answer: what activities can be supported, what business value can be gained and who could participate to achieve such values. In order to answer these questions, a comprehensive literature review is conducted and identified organizations can gain business value by identifying firm level operations that can enhanced by using these technologies. Furthermore, organizations will be better placed to gain value by engaging with employee, customers and other stakeholders through social technologies. Based on these finding a conceptual framework for effective usage of social technologies in each successive circle is proposed by considering external factors which could impede the effectiveness. This study is beneficial for organizations who are planning to deploy social technologies at workplace.

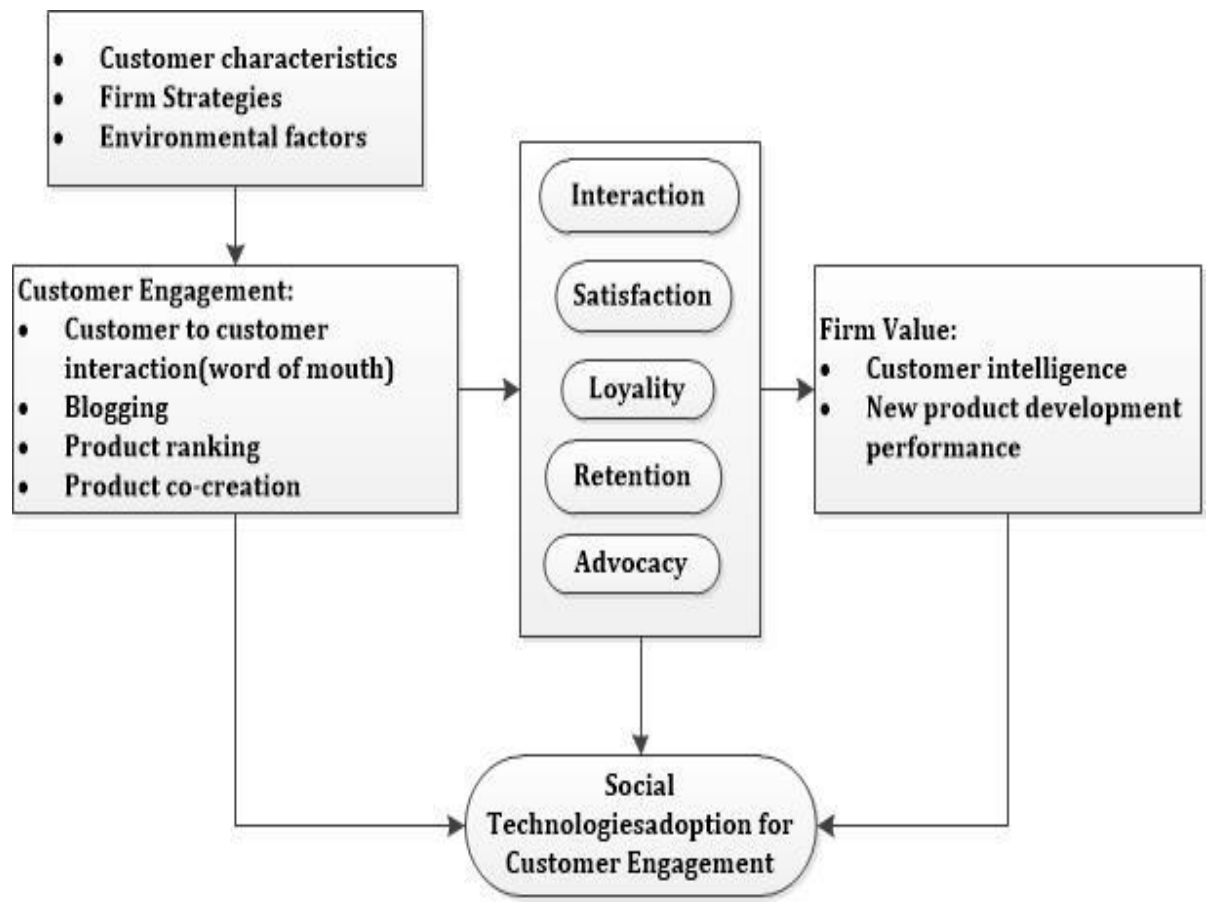

Fig. 5: Conceptual Model for Customer Engagement

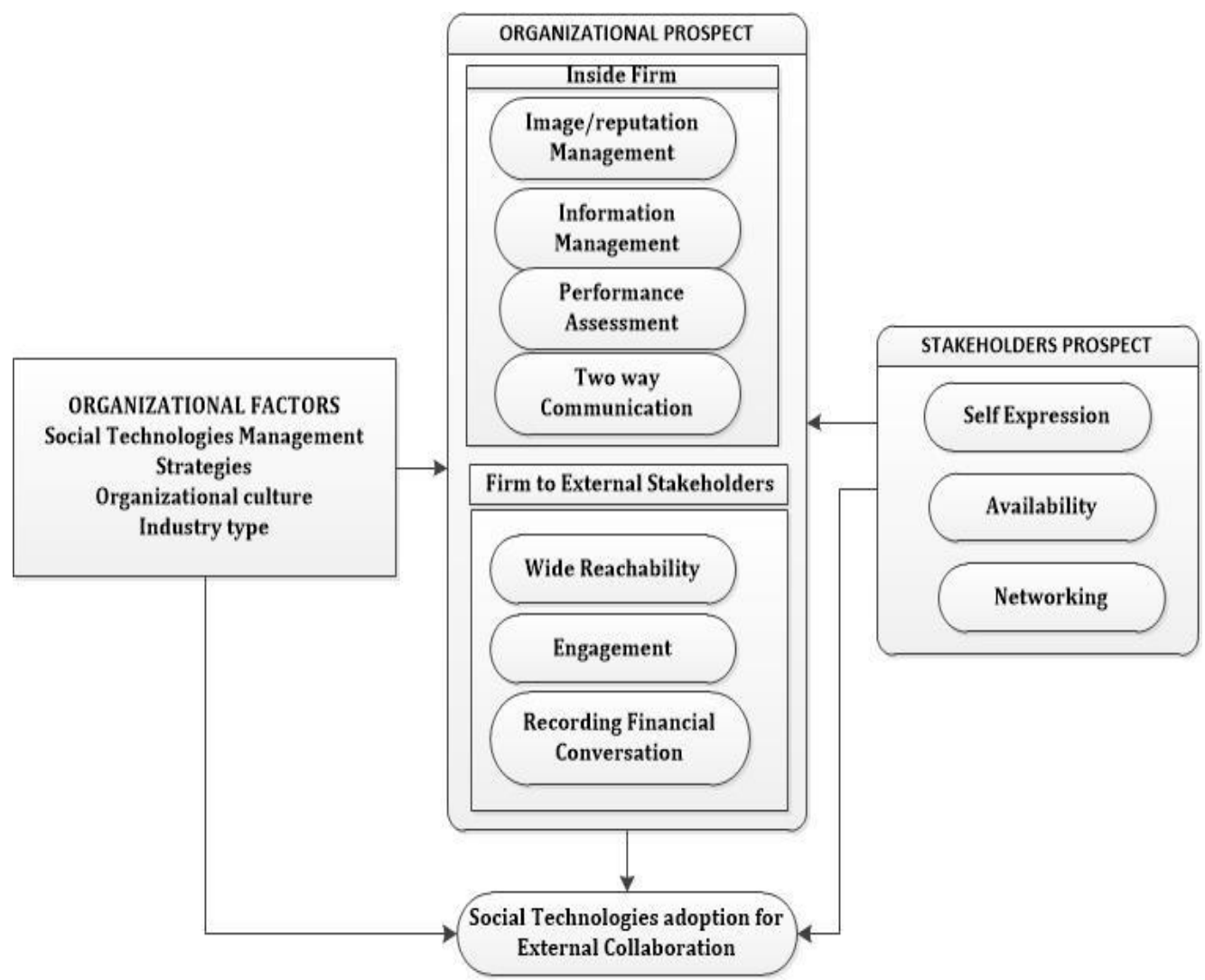

Fig. 6: Conceptual Model for Adoption of Social Technologies for Stakeholders Engagement 
Future research could validate conceptual frameworks by grounding this analysis in the field of information system and social science theories and implement this exploratory research using statistical analyses.

Table 1: Value gain by Organization by using Social Theologies

\begin{tabular}{|c|c|c|}
\hline Activity Supported & Sub Activities & Value gain \\
\hline \multicolumn{3}{|c|}{ Firm Level Usage } \\
\hline $\begin{array}{c}\text { Customer Relationship } \\
\text { Management }\end{array}$ & $\begin{array}{l}\text { Customer service and support } \\
\text { Product recommendation }\end{array}$ & $\begin{array}{l}\text { Cost savings, revenue, value creation, customer } \\
\text { satisfaction }\end{array}$ \\
\hline Competitive Intelligence & $\begin{array}{l}\text { Opinion making, Real time situation awareness. } \\
\text { Long and short term planning }\end{array}$ & Save time and cost of hiring experts to forecast \\
\hline Product Development & $\begin{array}{l}\text { Research and development, joint development of } \\
\text { new products/services through concretion }\end{array}$ & $\begin{array}{l}\text { Revenue, customer satisfaction, product/service } \\
\text { quality }\end{array}$ \\
\hline Branding & Advertising, content delivery & Cost savings, Company image enhancement \\
\hline $\begin{array}{l}\text { Communication and } \\
\text { collaboration }\end{array}$ & $\begin{array}{c}\text { Customer, Employee and stakeholder's interaction, } \\
\text { Real time contact }\end{array}$ & $\begin{array}{l}\text { Reduce external and internal communication cost, } \\
\text { Increase firm value }\end{array}$ \\
\hline Marketing & $\begin{array}{l}\text { Target marketing, personalize marketing, } \\
\text { recommend products }\end{array}$ & Time and Cost saving \\
\hline Promotions & $\begin{array}{c}\text { Sales includes "call for action"-e.g., link to } \\
\text { purchase item }\end{array}$ & Revenue \\
\hline Knowledge Management & $\begin{array}{l}\text { Improved Knowledge management, reuse } \\
\text { organizational contents }\end{array}$ & $\begin{array}{c}\text { Time and cost saving, Retention of organizational } \\
\text { cumulative knowledge }\end{array}$ \\
\hline Employee Monitoring & Performance monitoring, contents monitoring & $\begin{array}{l}\text { Increase productivity, decrease risk of sharing } \\
\text { confidential material, Increase accountability }\end{array}$ \\
\hline Recruitment & $\begin{array}{l}\text { Process efficiency, Quality of information, Large } \\
\text { talent attraction }\end{array}$ & $\begin{array}{l}\text { Shorten hiring cycle, Finding best match, Wide } \\
\text { applicant coverage }\end{array}$ \\
\hline \multicolumn{3}{|c|}{ Employee Engagement } \\
\hline $\begin{array}{l}\text { Creating/Accessing/ sharing } \\
\text { knowledge }\end{array}$ & $\begin{array}{l}\text { Improved Knowledge management, reuse } \\
\text { organizational contents }\end{array}$ & Reduce knowledge creation and transformation cost \\
\hline Learning and Training & Self-learning, information sharing & $\begin{array}{c}\text { Interactive peer feedback, timely delivery, cost } \\
\text { effective }\end{array}$ \\
\hline Networking and mentoring & Connecting with experts, Community formation & Increase learning, Job Satisfaction \\
\hline Communication & Interpersonal and organizational communication & Reduce internal communication cost and time \\
\hline $\begin{array}{l}\text { Monitoring Co-Worker and } \\
\text { organizational Activities }\end{array}$ & Building communities & Real time work environment awareness \\
\hline \multicolumn{3}{|c|}{ Customer Engagement } \\
\hline Customer Interaction & $\begin{array}{l}\text { Firm to customer and customer to firm } \\
\text { communication, Firm share their information and } \\
\text { collect customer feedback }\end{array}$ & Customer satisfaction \\
\hline Firm to Customer & $\begin{array}{l}\text { Promote contents, Distribute time sensitive } \\
\text { information. Recruit customer, assess }\end{array}$ & Increase revenue, Customer satisfaction \\
\hline Customer to firm & $\begin{array}{l}\text { Capture customer feedback, enhance market } \\
\text { research, augment customer service, foster } \\
\text { innovation, performance (To earn more "likes" as } \\
\text { an indicator for customer engagement) }\end{array}$ & Improve quality of service/product \\
\hline customer-to-customer & Firm can monitor inter customer dialogue & Yield customer insight as well as market intelligence \\
\hline \multicolumn{3}{|c|}{ Stakeholders Engagement } \\
\hline Information sharing & Delivering contents, advertisement & Firm social value \\
\hline Monitoring & $\begin{array}{l}\text { Capturing competitors understanding, Identifying } \\
\text { opportunities and risks, Forecasting competitor } \\
\text { moves }\end{array}$ & $\begin{array}{l}\text { Forecasting and timely action for opportunities and } \\
\text { risks }\end{array}$ \\
\hline External Collaboration & $\begin{array}{c}\text { Identify/reaching and dialoging stakeholders, } \\
\text { monitor investors' sentiments and respond to their } \\
\text { concerns }\end{array}$ & Reduce cost and time, earn stakeholders trust \\
\hline $\begin{array}{c}\text { Identifying unknown } \\
\text { stakeholders }\end{array}$ & $\begin{array}{c}\text { Identification of experts and potential business } \\
\text { partners }\end{array}$ & Finding best match at low cost \\
\hline
\end{tabular}

\section{References}

Bosch-Sijtsema PM and Haapamäki J (2014). Perceived enablers of 3D virtual environments for virtual team learning and innovation. Computers in Human Behavior, 37: 395-401.
Brown VR and Vaughn ED (2011). The writing on the (Facebook) wall: The use of social networking sites in hiring decisions. Journal of Business and Psychology, 26(2): 219-225. 
Bughin J, Chui M, and Miller A (2009). How companies are benefiting from Web 2.0: McKinsey global survey results. McKinsey Quarterly, McKinsey Global Institute, Seattle, USA.

Chai S and Kim M (2010). What makes bloggers share knowledge? An investigation on the role of trust. International Journal of Information Management, 30(5): 408-415.

Chidambaram L, Lim J, Chuan Chan H, and Han KU (2001). An empirical evaluation of organizational media use in Singapore. Journal of Global Information Technology Management, 4(1): $27-$ 44.

Davison RM, Ou CX, Martinsons MG, Zhao AY and Du $R$ (2014). The communicative ecology of Web 2.0 at work: Social networking in the workspace. Journal of the Association for Information Science and Technology, 65(10): 2035-2047.

Denyer D, Parry E, and Flowers P (2011). "Social","Open" and "Participative"? Exploring Personal Experiences and Organisational Effects of Enterprise 2.0 Use. Long Range Planning, 44(5): 375-396.

Dey L, Haque SM, Khurdiya A, and Shroff G (2011). Acquiring competitive intelligence from social media. Proceedings of the 2011 Joint Workshop on Multilingual OCR and Analytics for Noisy Unstructured Text Data (MOCR_AND '11), Article No. 3, New York, USA. https://doi.org/10.1145/2034617.2034621.

$\mathrm{Du}$ Plessis $\mathrm{T}$ and Boshoff $\mathrm{M}$ (2008). Preferred communication methods and technologies for organizational knowledge sharing and decision making: peer reviewed article. South African Journal of Information Management, 10(2): 1-18.

Farzan R, DiMicco JM, Millen DR, Dugan C, Geyer W and Brownholtz EA (2008). Results from deploying a participation incentive mechanism within the enterprise. Proceedings of the SIGCHI Conference on Human Factors in Computing Systems (CHI '08), New York, USA: 563-572. Https://doi.org/10.1145/1357054.1357145.

Gal-Tzur A, Grant-Muller SM, Minkov E, and Nocera S (2014). The Impact of Social Media Usage on Transport Policy: Issues, Challenges and Recommendations. Procedia-Social and Behavioral Sciences, 111: 937-946.

Gilbert E and Karahalios K (2010). Widespread worry and the stock market. Proceedings of the Fourth International AAAI Conference on Weblogs and Social Media: 59-65.

Giordano R (2007). An investigation of the use of a wiki to support knowledge exchange in public health. Proceedings of the 2007 international ACM conference on Supporting group work (GROUP '07), New York, USA: 269-272. Https://doi.org/10.1145/1316624.1316664.
Goh KY, Heng CS, and Lin Z (2013). Social media brand community and consumer behavior: Quantifying the relative impact of user-and marketer-generated content. Information Systems Research, 24(1): 88-107.

Gustafsson A, Johnson MD, and Roos I (2005). The effects of customer satisfaction, relationship commitment dimensions, and triggers on customer retention. Journal of Marketing, 69(4): 210-218.

Hadcroft P and Jarratt D (2007). Market orientation: an iterative process of customer and market engagement. Journal of Business-to-Business Marketing, 14(3): 21-57.

Hawn C (2009). Take two aspirin and tweet me in the morning: how Twitter, Facebook, and other social media are reshaping health care. Health Affairs, 28(2): 361-368.

He W, Zha S, and Li L (2013). Social media competitive analysis and text mining: A case study in the pizza industry. International Journal of Information Management, 33(3): 464-472.

Huh J, Jones L, Erickson T, Kellogg WA, Bellamy RK and Thomas JC (2007). BlogCentral: the role of internal blogs at work. In Extended Abstracts on Human Factors in Computing Systems (CHI EA '07), New York, USA: 2447-2452. Https://doi.org/10.1145/1240866.1241022.

Jussila JJ, Karkkainen $\mathrm{H}$ and Aramo-Immonen, $\mathrm{H}$ (2014). Social media utilization in business-tobusiness relationships of technology industry firms. Computers in Human Behavior, 30: 606613.

Kent ML, Taylor M, and White WJ (2003). The relationship between Web site design and organizational responsiveness to stakeholders. Public relations Review, 29(1): 63-77.

Kim AJ and Ko E (2012). Do social media marketing activities enhance customer equity? An empirical study of luxury fashion brand. Journal of Business Research, 65(10): 1480-1486.

Laroche M, Habibi MR, Richard MO (2013). To be or not to be in social media: How brand loyalty is affected by social media? International Journal of Information Management, 33(1): 76-82.

Lau KN, Lee KH, and Ho Y (2005). Text mining for the hotel industry. Cornell Hotel and Restaurant Administration Quarterly, 46(3): 344-362.

Lee K, Oh WY, and Kim N (2013). Social media for socially responsible firms: Analysis of fortune 500's twitter profiles and their CSR/CSIR ratings. Journal of Business Ethics, 118(4): 791-806.

Luo X, Zhang J, and Duan W (2013). Social media and firm equity value. Information Systems Research, 24(1): 146-163. 
McLennan A and Howell G (2010). Social networks and the challenge for public relations. Asia Pacific Public Relations Journal, 11(1): 11-19.

O'Leary C, Rao S, and Perry C (2004). Improving customer relationship management through database/Internet marketing: A theory-building action research project. European Journal of Marketing, 38(3/4): 338-354.

Rishika R, Kumar A, Janakiraman R and Bezawada R (2013). The effect of customers' social media participation on customer visit frequency and profitability: an empirical investigation. Information Systems Research, 24(1): 108-127.

Sashi C (2012). Customer engagement, buyer-seller relationships, and social media. Management Decision, 50(2): 253-272.

Schniederjans D, Cao ES, and Schniederjans M (2013). Enhancing financial performance with social media: An impression management perspective. Decision Support Systems, 55(4): 911-918.

Trainor KJ, Andzulis JM, Rapp A, and Agnihotri R (2014). Social media technology usage and customer relationship performance: A capabilities-based examination of social CRM. Journal of Business Research, 67(6): 1201-1208.
Trimi S and Galanxhi H (2014). The impact of Enterprise 2.0 in organizations. Service Business, 8(3): 405-424.

Wang M (2011). Integrating organizational, social, and individual perspectives in Web 2.0-based workplace e-learning. Information Systems Frontiers, 13(2): 191-205.

Wang X, Yu C, and Wei Y (2012). Social media peer communication and impacts on purchase intentions: A consumer socialization framework. Journal of Interactive Marketing, 26(4): 198-208.

Wattal S, Racherla P, and Mandviwalla, M (2009). Employee adoption of corporate blogs: A quantitative analysis. In 42 ${ }^{\text {nd }}$ Hawaii International Conference on System Sciences (HICSS'09): 1-10. Https://doi.org/10.1109/HICSS.2009.188.

Yu Y, Duan W, and Cao Q (2013). The impact of social and conventional media on firm equity value: A sentiment analysis approach. Decision Support Systems, 55(4): 919-926.

Zhao F and Kemp LJ (2012). Integrating Web 2.0based informal learning with workplace training. Educational Media International, 49(3): 231-245. 